\title{
Positive Influence of Religiosity on Income Growth of Believers: A Case of Africa Inland Church Tanzania in Mwanza City, Tanzania
}

Deborah Andrew Ngusa*

Department of Development Studies, The University of Dodoma, School of Social Sciences, Tanzania

\begin{abstract}
Religiosity to Africa Inland Church Tanzania (AICT) believers and other religions in this world has some positive influence on income growth due to its ethics that are compatible with development strategies. In development discourse, there has been a discussion about the initiatives to reduce poverty in poor communities by supporting people to become more independent and innovative. AICT is also a community that need to foster socio-economic development to its followers. This study focused on positive influence of religiosity on income growth of AICT believers in Mwanza City, Tanzania. Cross-sectional research design was employed to collect quantitative data through questionnaire. A Participatory Poverty Assessment (PPA) was employed to determine livelihood of individuals in the community. Purposive sampling was used to select 9 churches; 10 believers from each were selected through random sampling with the total of 90 respondents. Focus group discussions, semi-structured and life history interviews were employed to collect in-depth, qualitative data from the field. The study was enriched by secondary data that were collected from church documents. Data processing and analysis were done by summarizing, editing and coding. Content analysis was used to analyse in-depth data collected through life history interviews to develop two cases of respondents about the influence of religiosity on income growth in their lives. It is evident that religiosity has some ethics that have significant positive influence on income growth of believers. The study recommends that, religious leaders should integrate religious ethics related to income growth strategies to foster socio-economic development of their believers.
\end{abstract}

Keywords: Africa Inland church Tanzania; Believers; Ethics; Income growth and religiosity

\section{Introduction}

The current renaissance of religion in many parts of the globe has given rise to a growth in interest in the relationships between religiosity and income growth of those who follow its doctrines. The changes in religious ethics can significantly influence individual behaviour in the same way as conventional economic motivations, such as maximization of individual income and utility [1-3]. Barro and McCleary included the proportion of the population affiliated with each religious group as explanatory for the level of economic life [4]. They concluded that religious ethics, in economic terms, are the main output of religiosity as a whole, therefore, becomes a proxy for economic 'inputs.' Religion creates some ethics in individuals which relate positively with income growth and development in the community.

Various recent cross-country studies suggest that religiosity is a significant driver of income growth. This study focused on religiosity and income growth in AICT as one of the Protestant group in Christianity. According to Grier, Christianity has a broad series of doctrines that are significantly related to ethics which contribute to income and economic growth [5]. AICT grew out of the work of Africa Inland Mission (AIM) under American missionaries which began in 1909. AICT has been involved in promoting income growth by providing education and income generation programs to the community. The Bible is the foundation of the theological motivations that form the theology of income growth in AICT. The motivations provide reasons for Christians' involvement in income generation efforts, the methods and the goal of involvement originates from a Christian and Biblical perspectives. The starting point is God from whom and to whom all things belong. God creates and relates to the whole world [6-8]. Human beings are allowed to use God's creation to sustain their lives. In AICT, they apply the concept of holistic change that refers to the process of transforming the world and the lives of people so that relationships with God, others and the environment are restored. The term holistic is described by many different expressions such as integral mission, holistic transformation or development. Holistic implies combining different aspects so that they work together to bring wholeness to changes in mind-sets, attitudes and behaviours. Holistic change leads to increased productivity fostering income growth to people and communities [9]. According to AICT, holistic development accommodates spiritual and physical development to ensure socio-economic advancement of people in the congregations and reach out to other people in the community.

The social process for instance religious ethics affects and shape social and economic activities undertaken by believers. In Mwanza City, development mainstream involve a large number of religious groups and AICT as a dominant denomination in this area insists on some ethics that have positive influence on believers' participation in income generation activities [10]. Development agents invest their donations in religious institutions as non-profit organizations that focus on providing services to the community. As such, AICT has a great contribution of encouraging its believers to work hard for the sake of improving their livelihoods through participation in income generation activities. However, few studies analysed deeply religion's position on income generation activities and the positive influence is not clearly understood by the majority in the community. This study focused on the positive influence of religiosity on income growth of

${ }^{*}$ Corresponding author: Deborah Andrew N, Department of Development Studiies, The University of Dodoma, School of Social Sciences, Tanzania, Tel+ 25526 232 2848; E-mail: deborahngusa@yahoo.com

Received March 05, 2018; Accepted March 21, 2018; Published March 28, 2018

Citation: Ngusa DA (2018) Positive Influence of Religiosity on Income Growth of Believers: A Case of Africa Inland Church Tanzania in Mwanza City, Tanzania. Arts Social Sci J 9: 350. doi: 10.4172/2151-6200.1000350

Copyright: (c) 2018 Ngusa DA. This is an open-access article distributed unde the terms of the Creative Commons Attribution License, which permits unrestricted use, distribution, and reproduction in any medium, provided the original author and source are credited. 
AICT believers who adhere to the ethics preached in churches. It gives a better understanding of religious ethics and their possible contribution towards the income generation efforts of believers.

\section{Materials and Methods}

The study was conducted in Mwanza City located in the southern shores of Lake Victoria, in the north-western Tanzania. Mwanza is the second largest urban settlement in Tanzania. The city lies on the geographical location of $2^{\circ} 15^{\prime} 2^{\circ} 45^{\prime}$ latitudes South of the equator and between the $32^{\circ} 45^{\prime}$ to $33^{\circ} 00^{\prime}$ longitudes East of the Greenwich Meridian and an altitude of $1140 \mathrm{~m}$. The city covers an area of 256.45 Kilometre squares of which 184.90 (72 percentages) is dry land and 71.55 kilometre (28 percentages) is covered by water. According to the 2012 country Population Census report, the city has 2,772,509 people $(1,360,381$ males and 1,412,128 females). Mwanza City was selected because it is the second largest city in Tanzania that permits mapping in terms of religious attitudes [11]. In this city, AICT was selected as an influential denomination that has existed in the city since 1909.

A cross-sectional research design was employed to collect data from respondents. The design was used due to its potential for collecting data at a single point in time [12]. Prior to data collection, purposive sampling was used to select nine congregations from AICT as a targeted religious group which is dominant in the city. Participants for life history interviews, focus group discussions and key informants were also selected through purposive sampling technique. Random sampling was used to select 90 respondents, ten from each church for interviews and each believer had an equal chance of being included in the sample.

The study involved collection of primary and secondary data that were analysed to provide a comprehensive research report. Primary data collection employed structured questionnaire that was administered to 90 respondents from AICT to collect quantitative data. For qualitative data, focus group discussions, semi-structured and life history interviews were used to collect in-depth information. Two focus group discussions comprised of five church members and five leaders were conducted. The key informants were 10 church leaders, two district commissioners, four community development officers and four ward executive officers. Prior to the life history interviews, a Participatory Poverty Assessment (PPA) exercise was conducted to determine the standard of living of the community in general. The assessment was followed by grouping community members into strata that were used to explain upward and downward mobility of life history interview respondents. Participant observations were conducted by attending church programmes to record activities undertaken by the congregation members during church services. Secondary data were collected from the church database, profiles, constitution, service schedules, seasonal calendars, pamphlets and fliers to obtain information about the church system. Kwa Neema FM 98.2, as a religious radio station was visited to investigate recorded information about the level of religiosity in relation to believers' participation in income generation activities. Community development reports in Mwanza City were used to get information about people's income status.

The collected data from the field were analysed to provide descriptive, analytical and explanatory information to develop a meaningful research report. Both quantitative and qualitative data were analysed. For quantitative data, surveyed data were summarized, edited and coded before entering them into the data processing programme. Content analysis was used to analyse qualitative data from focus group discussions, key informants, observations and life history interviews by synthesizing information into themes to get in-depth information to explain respondents' experiences about the influence of religiosity on income generation activities.

\section{Results and Discussion}

\section{Age of respondents}

The study found in the study area that respondents have different age groups as a base to determine the work force involved in religious practices. Surveyed data reveals that most respondents $(35.5 \%)$ are from 26 to 40 years of age and (34.5\%) range from 41 to 60 years of age while $(24.5 \%)$ range from $16-25$ years of age, $(4.5 \%)$ from 60 years of age and above and $(0.9 \%)$ below 15 years of age (Table 1$)$. These results correlate with those of Noland (2005) who reported that the majority of believers are between the ages of 26 and 60 years old. He concluded that most churches are comprised of an active workforce capable of understanding various concepts in multi-discipline learning. In these churches, the majority of believers are in the middle age capable to understand religious teachings and integrate them with other aspects of their lives. Church leaders can use this opportunity to teach and encourage believers to become active in the process of implementing income generation efforts.

\section{Religious ethics in mainstreaming income growth strategies}

The findings in Table 2 show that the majority of respondents in AICT (75.8\%) disclosed that, religious ethics were liberal in making decisions and actions while (24.2\%) reported about conservative social attitudes in income generation efforts. This shows that religious ethics embrace liberalism in making decisions and actions underlying believers' engagement in income generation activities for their livelihoods. Believers had freedom to get engaged in a variety of income generation activities to improve their living standards. However, during focus group discussions they mentioned that their religious ethics prohibited them from selling alcohol, cigarettes and counterfeited goods regarded as un-sacred items but there were still more opportunities for income generation beside the ones rejected by their faith. The key informants also mentioned that, religiosity influences on how income generation initiatives were disseminated in the community. This observation is consistent with the findings of Rakodi who reported the freedom to mainstream income generation efforts to the full community without bias towards any group as the resilient strategy which is helpful for development agents in selecting and positioning development programmes and projects to reduce

\begin{tabular}{|l|l|c|c|}
\hline Aspect & Categories & Frequency & Per cent \\
\hline Age & Below 15years & 1 & 1.11 \\
\hline & 16-25 years & 23 & 25.56 \\
\hline & 26-40 years & 26 & 28.89 \\
\hline & 41-60 years & 35 & 38.89 \\
\hline & 61 years and above & 5 & 5.56 \\
\hline & Total & 90 & 100.0 \\
\hline
\end{tabular}

Table 1: Respondents' age $(\mathrm{N}=90)$.

\begin{tabular}{|l|c|c|}
\hline $\begin{array}{l}\text { Religious ethics in mainstreaming income } \\
\text { generation strategies }\end{array}$ & 66 & 75.8 \\
\hline $\begin{array}{l}\text { Liberal in making decisions and actions in } \\
\text { development }\end{array}$ & 24 & 24.2 \\
\hline Conservative social attitudes in development & 90 & 100.0 \\
\hline Total & & \\
\hline Source: Survey data 2011/2012 &
\end{tabular}

Table 2: Responses on mainstreaming in income generation strategies $(\mathrm{N}=90)$. 
poverty [13]. He explained the ways in which a belief system, or ties to religious ethics, affects decisions about whether and how income growth strategies are implemented in the community.

\section{AICT ethics compatible to income growth}

AICT has ethics that involve systematic concepts; recommended to be right and they have a significant contribution to increase participation in income generation activities of believers who follow them.

Positive attitudes towards hard working: Respondents in AICT reported that the knowledge of positive attitudes towards hard working is commonly addressed in church. During focus group discussions respondents explained their insights on good attitudes towards hard working and the way it can help people to deal with setbacks, get over disappointments and move forward in their lives. Good attitudes can bring more opportunities in people's lives and increase productivity. However, through observations some church members were poor lacked the ethics of hard working. Furthermore, some people were not making any kind of efforts to increase their incomes. These findings conform to those of Simbine who reported that laziness is a major obstacle in income growth and other aspects of lives [14]. The person must do whatever he is able to do and make use of his energy to generate income. Therefore, believers need to adhere to the ethics of hard working and use available opportunities wisely to generate income for the sake of improving the quality of their lives.

Honesty: The preaching and teachings by religious leaders play a significant role in imparting honesty to individuals. In fact, AICT believers who were employed said that when they showed honest at their work places, they gained acceptance from their supervisors, colleagues and the society. The issue of being honest is also insisted on in income growth as an important ingredient in exchange markets. This observation complies with those of Guiso et al. who reported that honesty is the social capital that plays an important role in the degree of financial development across different market places [15]. The level of social capital in the market enhances the level of interpersonal trust. Thus, the higher level of trust improves the efficiency of financial contracts and encourages provision of loans and credits from financial providers. However, in churches being honest is not clearly explained as one of the important ingredients in income growth. This shows that some believers lack knowledge about social capital as an important element in debt markets. Additionally, some believers explained their scepticism in taking loans by linking the failure to repay with lack of honesty. The fear of not being able to repay the debts can be destructive because loans are the good sources of capital in boosting income growth in the community. As such, entrepreneurship trainings are very important to teach people how to invest loans in their business to generate profits and repay the debts as well. Those who fail to take credits are likely to remain poor and lack confidences to launch businesses.

Frugality: Respondents reported that the issue of frugality is not seriously emphasized in selected churches. Frugality is the act of spending wisely and avoiding unnecessary expenditures. Along with saving, frugality makes a great contribution to building wealth. Some believers work hard and increase their income but they lack the spirit of frugality. Nyerere, the former president of the United Republic of Tanzania (1964-1985), when addressing financial issues, also insisted on the spirit of frugality by living an ordinary life as quoted by Kaduma in "The Legacies of Nyerere: Economies, Politics and Solidarity in Tanzania and beyond [16]. He said:

'If we all make up our minds to live like 'ordinary sort of fellows' and not to think that we were specially designed by the creator to be masters and others especially designed to be hawkers of wood and drawers of water we will make East Africa a very happy country for everybody" [17].

He further explained,

"Nyerere was a true African in thought, practice and aspiration. He was rooted in the African culture as it was reflected in his personal life style. His food was African from breakfast to dinner. He believed in the extended family but in a frugal way. His members of family lived most lives as he did, which is big contrast to most leaders who followed him or other leaders in Africa."

Nyerere was a role model as one of the great leaders in Africa whose life was rooted in the spirit of frugality and helping others. $\mathrm{He}$ shared what he had and extended his possessions to other members in his extended family. On the contrary, some people earn little but they expect to spend much. For instance, people plan, elaborate holiday celebrations which they are not able to afford. They waste and overspend money on luxury items. Lack of frugality can cause financial ruin by tempting people to spend irrationally. Lack of frugality undermines much of the hard work a person has done.

Stewardship: Stewardship as an ethic that embodies responsible planning and management of natural resources include respect to environment, economics, health, property, information and religion then linked to the concept of sustainability. Stewardship is one of the important religious ethics required for income growth, but it was not fully addressed in the study area. Interviewed individuals were not able to explain clearly the ways in which they integrated stewardship to their income generation activities. In AICT, stewardship is the idea that God created and therefore owns all of creation. Practically in development, stewardship emphasizes on wise use of resources and environment protection. Therefore, it is people's responsibility to use available resources wisely for the work of God and the work of man to increase their values. Stewardship was also emphasized on by the USAID survey findings which reported that wise use of environment is necessary in formulating and implementing income generating programmes/ projects [18]. This implies that people should avoid wasting resources and misusing them so that they can be used to enhance income generation efforts in the community.

Time management: Management of time was fully addressed in selected churches. Preaching and teachings emphasize on time as a scarce resource not to be wasted. O'Connor stated that time is a scarce resource which cannot be replaced nor recycled, it should be used wisely [19]. Believers were encouraged to make the best use of their time. Additionally, in development, time management is regarded as a crucial element in providing ample time for people to work on income generation activities. However, in some churches time was not well managed during church services due to lengthy programmes such as announcements, choirs, sermons, giving offerings and tithes and fund raising. Traditionally, the way of living and weak socio-economic infrastructures result in time-waste. The way people use their time has great impact on income growth for individuals, households and communities.

\section{Case Studies on religiosity and income growth of AICT believers in Mwanza City, Tanzania}

The in-depth analysis on the positive influence of religiosity on income growth of believers was done by coding data from life history interviews at individual level that were explained by using trajectories. The following cases were collected from two devoted believers of AICT in Mwanza City: 


\section{Case No. 1: Joseph (M) from Igoma Street in Nyamagana District}

The results in Figure 1 illustrates Joseph's multiple-step declining life trajectory mainly caused by the early deaths of his father and chronic health problems he suffered after retirement but not in a critical condition. Joseph was a man of 63 years old who was born in 1949 in Kwimba District. His father was Bahebe and his mother was Suzana. Joseph was raised in a family that adhered to traditional belief structure in the Sukuma culture. He appeared to be very curious about interview and paid attention.

Joseph's household grew cash and food crops such as cotton, rice, maize, sorghum/millet, cassava, sweet potatoes and groundnuts. Farming was their main source of income and it was sufficient to provide for family basic needs. They possessed the following assets; two grass thatched houses, twenty acres of land, ox-plough and livestock such as cattle, goats and sheep [20]. The two houses were built with mud walls; one of them was grass thatched and the second one was steel roofed. The main house had two rooms and a simple siting room. The house compound was simple and was surrounded by trees. Joseph also managed to build his own house in 1979 which had block brick walls, well roofed with steel, good ventilation, three bedrooms and one sitting room. There were some flowers in containers arranged beside the front view of the house. However, his parents' houses were inferior to his house. Additionally, his house was located in town but his parents' houses were in the village.

Joseph was converted into Christianity in 1959 and became a believer in AICT denomination. His pastor introduced him to the idea of going to school so that he can learn how to write and read. He accepted the idea, but he faced a difficult situation in 1960's when his parents opposed his decision to go to school [21]. However, the pastor and himself managed to convince his parents and pursued primary education from 1960-1967. In 1969, he was employed by Mwanza Textile Industry (MTI) as a security guard officer. He earned enough income to provide for his needs and remittances to his parents. He was committed to performing his duties because he was guided by religious principles. He maintained his position by encouraging others to work hard and as a supervisor he treated them with dignity. At the age of 27, his parents proposed Loyce from the same ethnic group to be his wife. He accepted his parents' suggestion and the bride price arrangements were made under the Sukuma culture. His parents paid the bride price and they got married in 1976. Their marriage was officially ordained in AICT as a monogamous union in the relationship of one man and one woman.

His mother was impressed by his behaviour and the teachings taught in church. She differentiated him from his siblings who spent their income for luxurious items such as drinking, smoking and adultery. Therefore, she was converted to Christianity in 1990 within AICT denomination through Joseph's testimony. He avoided his colleagues' companionships because they were addicted with alcoholism and smoking and they lived immoral lives against to the AICT doctrines. Some of them were fired from work because their performances at their workplaces were poor. But, Joseph was trusted by his supervisors because he followed the rules and regulations at his workplace. $\mathrm{He}$ abided in the religious rules of working faithfully with commitment and become trustworthy as he narrated:

"The ways I conduct my daily activities, I abide on religion ethics and values. There are several principles from my religious ethics that help me to develop a habit of hardworking and self-motivated at my workplace. I also learn to spend my income wisely by avoiding wastage of my wealth for unnecessary items. I can save my income and use it to improve my living standard such as building a house and supplying basic needs for my household".

Joseph applied his religious ethics and values to ensure that he worked very hard and faithfully at his workplace. However, in 1993 his life happiness decreased when his father died. Furthermore, in 1995 he lost his employment in MTI due to industrial bankruptcy. But, he got another employment in 1997 at Mwanza Breweries Company (MBC) as an assistant to the human resource manager. Joseph retired from his employment of breweries in 1999 and continued with farming. He produced crops such as rice, maize, legumes, cassava, sweet potatoes and vegetables. Apart from that, he volunteered to work as a church elder, secretary in AICT Igoma Local Church and choir member as well at the same congregation. However, he experienced another horrible

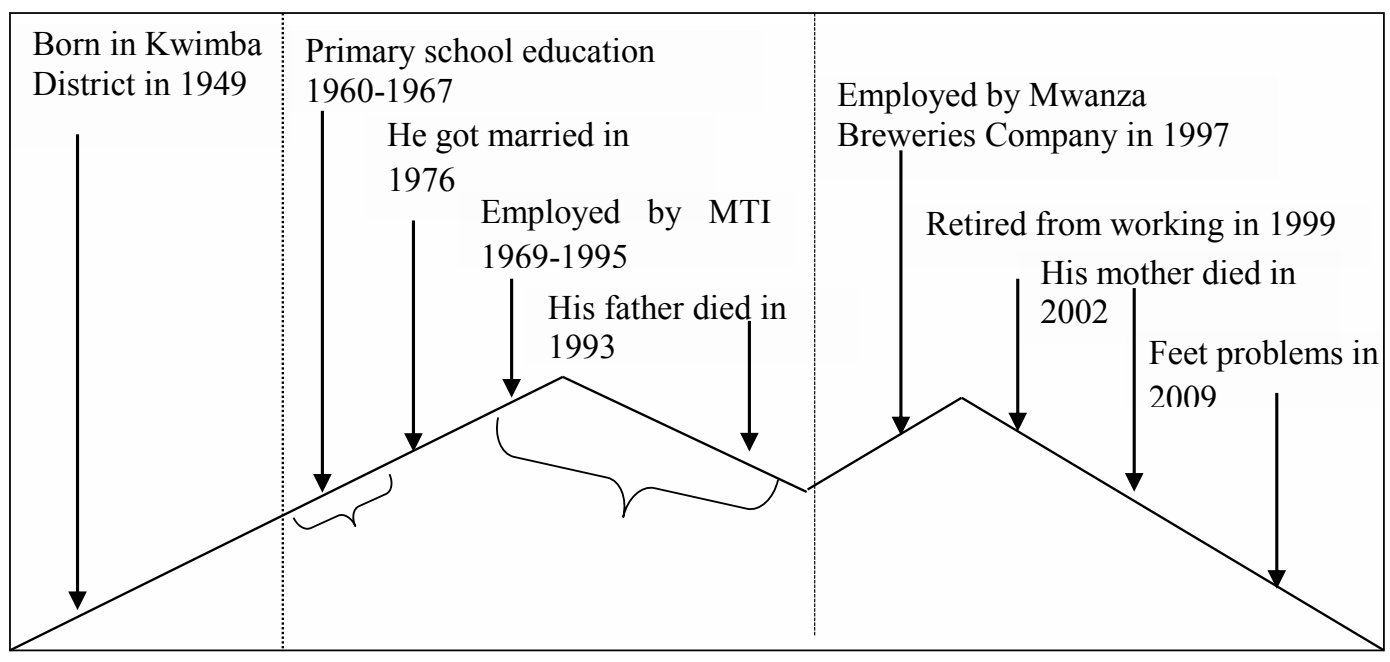

Source: Survey data 2011/2012.

Figure 1: Declining multiple-step: Joseph 
moment when his mother died in 2002. In 2009, he started suffering from feet problems that caused pains especially during the night time.

The multiple-step declining trajectory reveals various horrible circumstances Joseph faced in his life. In all situations, he was encouraged by some ethics he adopted from church and he believed that God was in control of the circumstances happened in his life. He considered religious ethics as significant in his life. Religious commitment affected his life positively as he narrated during his life history interview:

"There is a huge gap that exists between my age mates and myself. They have devoted their lives towards drunkenness, smoking, polygamous marriage and adultery. I chose to be a religious person which helped me to stay away from my peer group because they lived immoral lives. If I had followed my friends' life styles, it would not have been possible for me to have a good life. Being a believer shaped my behaviour and activated me to plan for income growth."

Life choices around his religious orientation helped him to behave wisely and avoid unproductive companionships. He made decisions based on the doctrines taught in his denomination about how to behave as a Christian with loyalty that greatly contributed to increase his performance at his workplaces (Figure 1).

\section{Case No. 2: Rose-Mary from Pasiansi in Ilemela District}

The case of Rose-Mary (Figure 2) illustrates a saw-tooth declining trajectory mainly caused by the death of family members. Rose-Mary was a lady of 36 years old who was born in 1975 in Ilemela District. Rose-Mary appeared to be happy with the interview because she was a good communicator and a public speaker. She responded with enthusiasm and welcomed the researcher at her home. Her house was modern; roofed with smooth iron sheets, tiled floors and fancy rocks in some parts of the walls. The house was surrounded by flowers and trees. It was also fenced by walls and posts. It had five bed rooms, one living room, dining room, kitchen and office. As a couple, they owned one house, home appliances (cookers, refrigerators and microwave), furniture (coaches, tables, chairs, cupboards and beds), media instruments (radio, television set, cassettes, and Digital Versatile Disc (DVD) player), piece of land (32 acres) and 3 residential plots of low density in Mwanza City.

Rose-Mary explained her background since childhood stage. During her childhood, she lived in a family of Roman Catholic believers. She learned and practiced religious ethics at home and church as well. Her father was employed as a district education officer in Shinyanga. He was also involved in coaching a soccer team and had a carpentry workshop. Her mother worked in Shinyanga Regional Cooperative Union (SHIRECU) and had an extra business of selling cotton oil and clothes. Her parents earned enough income to provide for the household needs. They used their income to accumulate assets such as house, 30 acres of land, home appliances (cooker and refrigerator), media instruments (television set, radio, Digital Versatile Disc (DVD) player) and furniture (coaches, chairs, tables and cupboards). Their house was built of cement and block bricks with smooth iron sheets roof. It had six bed rooms, dining, kitchen and sitting room. The house was surrounded by a few trees and flowers. It was not easy to grow many plants because their house was built in a dry area.

In 1982, Rose-Mary suffered from severe nose bleeding. After recovering, she started primary school in 1983 and completed standard seven in 1989. In 1993, she completed secondary education. She received a certificate in teaching in 1996. She worked as primary school teacher in the city of Mwanza. In 1997, she married Leonard who was an AICT believer. She enjoyed married life that was officiated in AICT. She continued with her Christian life and worshiped in AICT with her husband. Both of them earned enough income to meet their personal and household needs. Her husband was employed by Magu District council as a treasurer. She had a good standard of living in her household but she experienced frequent death events of her close family members. Her mother died in 2001, her father in-law died after six years in 2007 and one year later in 2008 her ten year old daughter died suddenly after struggling with severe malaria for almost six hours. She managed to handle all these horrible events and she trusted in God's comfort based on AICT doctrines.

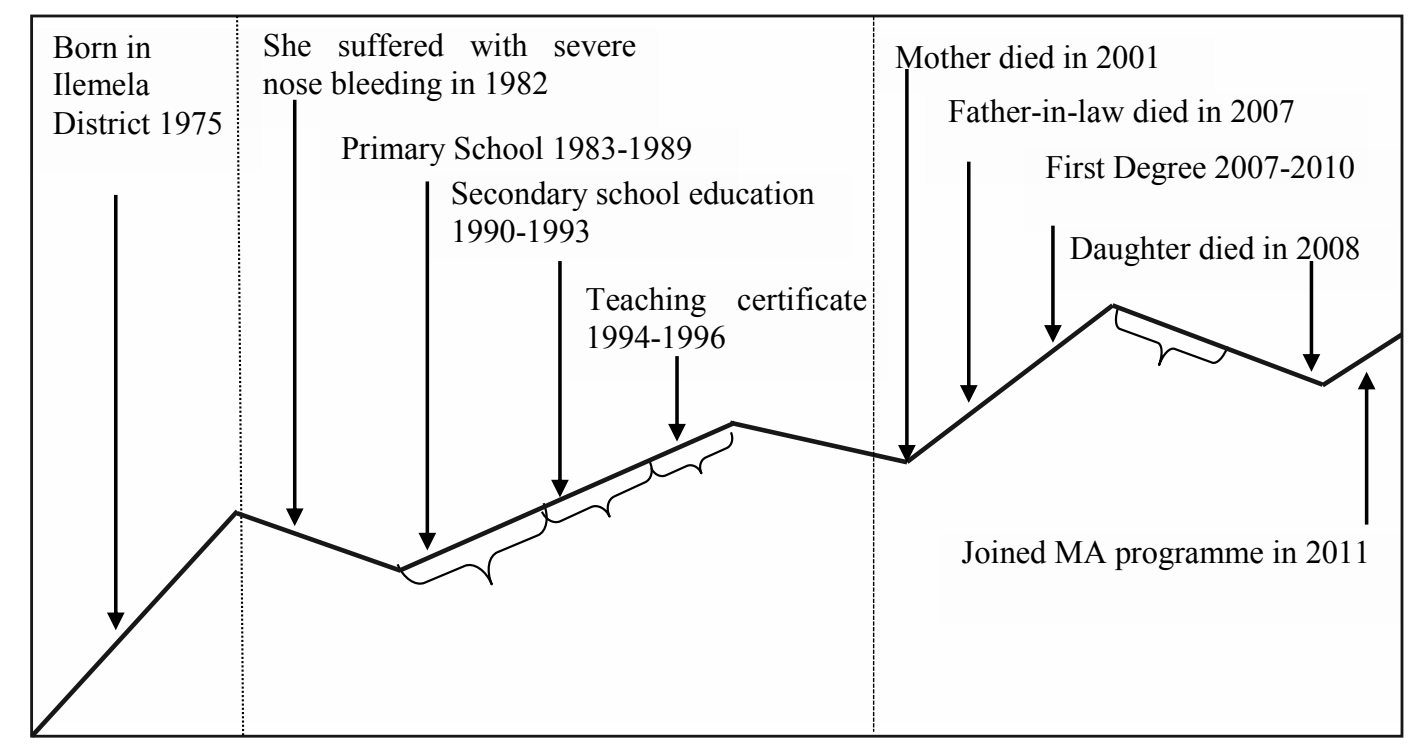

Source: Survey data 2011/2012.

Figure 2: Declining saw-tooth: Rose-Mary 
Rose-Mary continued with academic venture and in 2010, she completed her first degree in education at Saint Augustine University of Tanzania (SAUT) in Mwanza. In 2011, she joined a Master of Arts program in the field of Management and Planning at the same university and graduated in 2013. Her responsibilities increased as she decided to support other people who were vulnerable such as orphans and widows. In order to raise their household income, they run enterprises for computer accessories, electricity backup systems and a solar energy manufacturing system. She also had charitable ministries such as helping widows and orphans with financial and moral supports, restoration and complete healing for church leaders and empowerment in development for women and youth. Her life operated and she implemented various strategies insisted in AICT doctrines about entrepreneurship as she narrated:

"I always adhere to religious ethics, beliefs and values in everything I do in my life. After learning from various sessions in church, I put the materials into practices. I believe in working hard to improve my living standard as it has been insisted by our church leaders. Before starting any business, I dedicate it to God and ask Him to strengthen me during all the stages. Believing that God is with me, I can work confidently and succeed".

She stated that, religious ethics relates to some principles which are able to foster income growth when believers put them into practices. She believed in the religious ethics that encourage believers to work hard and avoid laziness, being honest, maintain frugality, observe stewardship and manage time have reinforced her to participate fully in income generation activities for making profits.

In general, Rose-Mary and her family lived a decent life. However, the saw-tooth declining trajectory reflects the three deaths of her close family members. But her financial status was not affected by these devastating events. She applied religious doctrines in income generation and succeeded.

\section{Conclusions and Recommendations}

In AICT, the majority of believers are in the middle age, they have strength to put into practice the religious ethics that relate with income growth of improve their living standards. It is evident that religiosity in terms of the ethics that are compatible with income growth, it has positive influence to foster socio-economic development at individual, household and community levels. In AICT, believers have freedom to engage in a variety of income generation activities but there are few restrictions that are not harmful to their choices of enterprises because there are several opportunities available in their area. Religious ethics such as positive attitudes towards hard working, honesty, frugality, stewardship and time management are significant attributes to foster income growth of believers when they are analysed based in the concept of socio-economic development for livelihood outcomes. The religious ethics encourage believers to engage on income generation activities to reduce poverty in their households. The life history interviews provided qualitative evident from participants who testified their success in income growth after adhering to religious ethics.

Therefore, the study suggests that religious leaders should teach their doctrines and integrate them with income growth of believers by insisting in adoption of the ethics compatible with socio-economic development goals. Thus, they should make sure that they address misleading concepts that are against their fully participation in income generation activities to ensure that they abide in the standard principles of socio-economic development to improve their livelihoods. Furthermore, religious leaders should collaborate with loan officers and launch workshops for teaching AICT believers on how to invest loans in business to get profits and repay the debt to increase their income.

\section{Acknowledgement}

I would like to acknowledge Kim Abel Kayunze a Professor in Rural Development at the Development Studies Institute (DSI) of Sokoine University of Agriculture (SUA) for proofreading this paper.

\section{References}

1. Mangeloja E (2004) Economic Growth and Religious Production Efficiency. Paper presented at the 3rd Annual Conference on Religion, Economics and Culture, Kansas City, Missouri.

2. Gahnström CSL (2012) Ethnicity, religion and politics in Tanzania: The 2010 general elections and Mwanza region (Doctoral dissertation).

3. Bielefeldt AR, Canney NE (2016) Relationships between religion, spirituality and socially responsible engineering. Journal of Engineering Studies, pp: 66-90.

4. Barro RJ, McCleary RM (2003) Religion and Economic Growth. Across Countries. American Sociological Review 25: 760-781.

5. Grier R (1997) The Effect of Religion on Economic Development. A Cross national 13 Study of 63 Former Colonies. Kyklos 50: 47-62.

6. Chinyong'ole J (2005) The Anglican Church and Poverty in Tanzania. A Review of Development Programmes in the Diocese of Morogoro.

7. Kipacha A (2010) The Relationship between Values, Religious Teaching and Development Concepts. Makumira University College, Arusha, Tanzania, p: 27.

8. Mhina A (2007) Religious and Development in Tanzania. A Literature Review: Religions and Development Research Programme.

9. Mercer C, Green M, Mesaki S (2010) The development activities, values and performance of non-governmental and faith-based organizations in Magu and Newala districts, Tanzania, pp: 24-32.

10. Gahnström CSL (2012) Ethnicity, religion and politics in Tanzania: The 2010 general elections and Mwanza region (Doctoral dissertation).

11. Babbie EP (1998) Survey Research Methods (2ndedn), Wadsworth Publishing Company Belmount, Califonia, p: 395.

12. Rakodi C (2007) Religion and Development. Understanding the Roles of Religions in Development. The Approach of the Religion and Development Programme, p: 43

13. Simbine AT (2011) Religion, Ethics and Attitudes towards Corruption in Nigeria

14. Guiso L, Sapienza P, Zingalez L (2003) People's Opium? Religion and Economic Activities. Journal of Monetary Economics 50: 225-282.

15. Kaduma I (2010) Maadili ya Taifa na Hatma ya Tanzania. Knowledge Printers and Publishers, Dar es Salaam, Tanzania, p: 30

16. Julius N (1966) Freedom and Unity. Oxford University Press, pp: 24-29.

17. USAID (2010) Biodiversity Conservation: A Guide for USAID Staff and Partners

18. O'Connor K (2003) O'Connor Living in Kingdom Time, Time management for Busy Christians.

19. Barro RJ, McCleary RM (2003) Religion and Economic Growth. Across Countries. American Sociological Review 25: 760-781.

20. Mangeloja E (2004) Economic Growth and Religious Production Efficiency. Paper presented at the 3rd Annual Conference on Religion, Economics and Culture, Kansas City, Missouri.

21. Noland M (2005) Religion, Culture and Economic Performance. 